\title{
Working Environment and its relation to Head Nurses' Organizational Citizenship Behavior and Managerial Innovation
}

\author{
Awatef Hassan Kassem $^{1}$ \& Maysa Fekry Ahmed ${ }^{2}$ \\ 1. Assist. Prof in Nursing Administration Department, Faculty of Nursing, Mansoura University, Egypt \\ 2. Lecturer in Nursing Administration Department, Faculty of Nursing, Mansoura University, Egypt
}

\begin{abstract}
Background: An attractive working environment is one of critical factors that assist head nurses to improve citizenship behaviors and encourage their innovation. Aim: The study aimed to investigate working environment and its relation to head nurses' organizational citizenship behavior and managerial innovation at Main Mansoura University and Elmahala General hospitals. Methods: The study was conducted in all inpatients at both hospitals. The total sample was 140 head nurse. Three tools were utilized: working environment, organizational citizenship behavior and managerial innovation questionnaires Results: The result showed total agreement of working environment at Main Mansoura University Hospital was higher than Elmahala General Hospital. Also the total agreement citizenship behavior was highest at Elmahala General Hospital rather than Main Mansoura University Hospital. Finally, total agreement of managerial innovation at Main university hospital was higher than at Elmahala General Hospital. Conclusion: This study concluded that statistically significant positive relationship between working environment with both variables. So, a probability of enhancing organizational citizenship behaviors and managerial innovation throughout enhancing their working environment. Recommendations: Healthcare administrators must focus to improve healthcare working environment that nurtures organizational citizenship behavior and innovation.
\end{abstract}

\section{Keywords: Head nurses, Managerial innovation, Organizational citizenship behavior \& Working environment.}

\section{Introduction}

Working environment of healthcare professionals is changing dramatically and rapidly causing fundamental transformations that have an impact on head nurses' performance. An attractive and helpful working environment is one of the most critical factors that assist head nurses to perform to their highest ability, creating best utilization of their knowledge, skills and capabilities, improve head nurses citizenship behaviors and encourage their creativity and innovation (Massoudi\&Hamdi, 2017). The working environment is a broad and complex concept with several perspectives. It is the setting in which head nurses interact, the social features and physical conditions in which nurses perform their jobs and devote greatest of their working times (Rachman, 2019). Additionally, it is consider as those conditional characteristics that affect innovative actions as features of the job, work location, and relations with colleagues and superiors (Sutanto, et al., 2018)

A positive working environment is a workplace that promotes head nurses safety, growth and goal attainment. It containing proper and adequate facilities that a head nurse may want in a work place (Akinwale \& George, 2020). It is a creative, motivating, pleasurable, and well for managers, head nurses, staff nurses and patients. It affects head nurses' practices, supporting their growth and making them feel safe and comfortable, giving them positive emotions and motivating them to do their bests, be more committed and willing to exert efforts and easily offer their time and energy to succeed at the allocated work and exceed their basic job requirements and behave as a citizen (Pranitasari, 2019)

Organizational citizenship is one of the major attitudinal variables in the scope of employment and job and it has significant importance in the workplace. It has been importantly useful for today's organization toward overall organization effectiveness (Awang, et al., 2019). Organizational citizenship behavior (OCB) is used to describe the entire positive and constructive head nurses actions and behaviors that aren't part of their formal job description. Organizational citizenship behavior arises in several different forms and shapes and it is a coping activity which emerged as a result of positive emotions (Agbozo, et al., 2017).

OCB is a multidimensional concept that contains everything positive. OCB is the readiness of members to exert effort beyond the official responsibilities commanded by their positions. It is an individual, unrestricted behavior, not clearly identified by the official incentive system, which helps to the organizational effective working (Bellini, et al., 2019). 
OCB is not something that's required from nurses to do their job and it's not part of their contractual tasks. These activities are frequently internally interested, rising from and continued by an individual's internal want for a feeling of accomplishment, competence, belonging or affiliation. It's anything that head nurse do, out of their own free will, that supports their colleagues and benefits the organization as a whole (Alabduljader, 2019)

Promoting and instructing organizational citizenship behavior is one of the most important and required concept today to meet the organization's expectations. OCB of the head nurses, is one of the most effective determinants for the organizational dynamic growth and innovation (Asurakkody \& Shin, 2018) Innovation is the process of developing novel ideas, methods, technologies and techniques of working. It begins with a good idea, but it is greatly more than that. Innovation in nursing is around motivating head nurses to utilize their knowledge and skills to alter the old methods of thinking, and performing \& to grow novel techniques of working that really enhance nursing practice. It also refers to the process of rotating that good idea into something that can be utilized, something that is achievable, attainable and hopeful (Weintraub \& McKee, 2019) Managerial innovation is the introduction of recent management practices, procedures, and structures that are planned to additional organizational goals and represents important alteration in the manner that managerial work is achieved and how managers seek to achieve the objectives of the organization (Drosos, et al., 2021) Managerial innovation, then, relates to alterations in how managers establish instructions, make judgments, organize actions, and stimulate people. It creates a change in the shape, quality, or state over time of the management activities in an organization (Najm \& Alhmeidiyeen, 2019).

Managerial innovation is becoming a significant issue and essential approach for organizational effectiveness and competitiveness. Managers encourage innovation through simplifying novel thinking, new thoughts, and recent ways of working among the workers, which improve organizational action and enhance its internal and external image (Zhang, et al., 2018). There are three dimensions of managerial innovation: practices, processes, and structures (Asurakkody \& Kim, 2020).

There are many factors affecting innovation as a good working environment with adequate resources including everything that helps the head nurses in completing their work (Khan, et al., 2018). Also, organizational incentive to innovation, that is made up through the worth the association puts on the innovation, organizational support, work team supports, supervisory reinforcement and autonomy to select how to perform one's work. As well as individual characteristics as an openness to novel ideas and having an optimistic attitude to innovation and change, higher utilization of new information and enthusiasm for more training and education (Akbari, et al., 2021).

\section{Significance of study}

In the rapid changes and competitiveness of health care systems around the world, working environment is associated with all outcomes for both the head nurses and organizations. So, working environment is a matter of great concern because most of us spend an enormous amount of our lives at work and we all hope to have good working environment (Omidi, et al., 2018).

Organizational citizenship behavior and managerial innovation are a critical factors for developing organizations. They affect head nurses' practices, efficiency, giving them positive emotions and motivating them to do their bests and exceed their basic job requirements (Utami, et al., 2020).So, organizations strive to recruit and retain talented and innovative head nurses who behave like citizens, and it is difficult to achieve it without supportive working environment. Hence, hospital managers need to assess the working environment and take actions to improve it.

Some studies have been conducted in USA to increase understanding about working environment and organizational citizenship behavior as the influence of the work environment, organizational commitment and organizational citizenship behavior on employee performance and motivation as intervening (Rachman, 2019). Organizational citizenship behavior on nurses: The role of organizational commitment and job satisfaction (Adnans, et al., 2020). And, organizational citizenship behavior and organizational commitment among clinical nurses in Bangladesh (Hossain, 2020). The studies done in Egypt focus on the impact of working environment on achieving managerial innovation (Ramadan, 2018). The relationship between organizational support, work engagement and organizational citizenship behavior as perceived by staff nurses at different hospitals (Abed \& Elewa., 2016). No attempts were done to examine working environment and its relation to head nurses' organizational citizenship behavior and managerial innovation at Main Mansoura University and Elmahala General Hospitals. Therefore, this study aims to investigate working environment and its relation to head nurses' organizational citizenship behavior and managerial innovation at Main Mansoura University and Elmahala General Hospitals. 
Aim of the study

The study aims to investigate working environment and its relation to head nurses' organizational citizenship behavior and managerial innovation at Main Mansoura University and Elmahala General Hospitals.

Research questions

- What is the level of working environment as perceived by head nurses?

- What is the level of organizational citizenship behavior as perceived by head nurses?

- What is the level of managerial innovation as perceived by head nurses?

- Is there a relation between working environment and both head nurses' organizational citizenship behavior and managerial innovation at Main Mansoura University and Elmahala General Hospitals?

\section{Methods \\ Design:}

A descriptive correlational research design was utilized to carry out this study.

\section{Setting:}

All inpatient departments at Main Mansoura University hospital with beds capacity 1800 and the hospital represent Ministry of Higher education and found in Mansoura City followed Dakahelia governorate and provides different health care services, and all inpatient departments at Elmahala General Hospital which represents Ministry of health and found in Elmahala city followed Gharbia governorate and provides different health care services for chest patients.

\section{Subjects}

Convenience sample of all available head nurses at Main Mansoura University and Elmahala general hospitals $(n=105, n=35)$ respectively at the time of data collection in different setting as mentioned.

Tools of data collection: There are three selfadministered questionnaires were used as followed:-

Tool I: Work Environment Questionnaire: This tool was developed by Alabduljader, (2019) and it consists of two parts:

First part: Personnel characteristics of head nurses as age and years of experience.

Second part: Working Environment Questionnaire: It aims to assess working environment as perceived by head nurses. It is measured by a 27 - item under six main dimensions, which are facilities (4 items), management support (4 items), teamwork (5 items), safety and security (4 items), work stressor (5 items) and finally recognition and appreciation (5 items). Responses were scored on a three points Likert rating scale ranged from disagree, uncertain, and agree were scored correspondingly as 1, 2, and 3. Scoring system was used: $<50 \%$ low level of working environment, $50 \%-75 \%$ moderate level and $>75 \%$ high level of work environment based on cut of point.

Tool II: Organizational Citizenship Behavior Questionnaire: This tool was developed by Fox \& Paul, (2011). It is used to assess the head nurses' organizational citizenship behavior. It consists of 39 items, divided into 5 main dimensions which are: Training and development (6 items), work life policies (4 items), empowerment practices (9 items), organizational commitment (8 items), and finally, interpersonal harmony (12 items). Responses were measured on a three-points rating scale ranged from 1=disagree, $2=$ uncertainly and $3=$ agree. Scoring system of (Abd - Elmohsen, 2017) was used: <50\% low level of citizenship behavior, 50\% - 75\% moderate level and $>75 \%$ high level.

Tool III: Managerial Innovation Questionnaire: It was developed by Alabduljader, (2019) and aims to assess managerial innovation among head nurses. It contains eight items as I always look for new ways to manage my team, I do not manage in a conventional way, New ideas and ways are always good and are welcomed and etc,. Answers were measured on a three-points rating scale ranged from disagree, uncertain, and agree were scored correspondingly as 1,2 , and 3. Scoring system was used: $<50 \%$ low level of managerial innovation, $50 \%-75 \%$ moderate level and $>75 \%$ high level based on cut of point.

\section{Validity and reliability}

The tools were translated by the researchers into Arabic, and tested for its content validity and relevance via five experts in nursing administration from faculties of nursing (Mansoura \& Tanta nursing faculties), and consequently the needed alteration was completed. The reliability for the tools were done using cronbach's alpha test. It was (0.91) for working environmental questionnaire, (0.89) for organizational citizenship behavior, and (92) for managerial innovation questionnaires.

Pilot study

A pilot study was done on $10 \%$ (15 head nurse) of head nurses working at Main Mansoura University and Elmahala General Hospitals that randomly selected and excluded from the study contributors to check and confirm clearness and applicability of the tools.

\section{Ethical considerations}

Ethical approval was gotten from the Research Ethical Committee of Faculty of Nursing, Mansoura University, sharing in the study was voluntary, and confidentiality of the gathered data was sustained. Privacy of the study sample was secure, as well as the findings were utilized as a component of necessary research, and for future publications and education. 
The reason of this research was clarified to the administrative persons, the written agreement was attained from the faculty of nursing, Mansoura University to the hospital administrators to perform this study.

\section{Data collection}

The actual field work started from January to May 2021. Data collected through meeting with the head nurses, and explains the purpose of the study to them. The questionnaire sheets were allocated to participants discretely in their job places, and the time required to complete the questionnaires ranged from 25-30 minutes.

\section{Data analysis}

The gathered data were prepared tabulated and statistically analyzed utilizing SPSS software
(Statistical Package for the Social Sciences, version 22, SPSS Inc. Chicago, IL, USA). For quantitative data, the range, mean as well as standard deviation were estimated. For qualitative data, comparison between two groups and further was done utilizing Chi-square test (2). For comparison between means of two groups of parametric data of independent samples, student t-test was utilized. For similarity between means of two groups of non-parametric data of independent samples, $\mathrm{Z}$ value of Mann- Whitney test was utilized. Relationship between variables was calculated utilizing Pearson's correlation coefficient (r). Significance was adopted at $\mathrm{p}<0.05$ for explanation of findings of tests of significance.

\section{Results}

Table (1): Personal characteristics of the studied head nurses $(n=140)$.

\begin{tabular}{|c|c|c|c|c|c|c|}
\hline \multirow{3}{*}{ Variables } & \multicolumn{6}{|c|}{ The study head nurses $(n=140)$} \\
\hline & \multicolumn{2}{|c|}{ MMUH (n=105) } & \multicolumn{2}{|c|}{ EGH $(n=35)$} & \multicolumn{2}{|c|}{ Total $(n=140)$} \\
\hline & $\mathbf{N}$ & $\%$ & $\mathbf{N}$ & $\%$ & $\mathbf{N}$ & $\%$ \\
\hline $\begin{array}{l}\text { Age } \\
\text { - } 25-35 \\
. \quad>35 \\
\end{array}$ & $\begin{array}{l}54 \\
51 \\
\end{array}$ & $\begin{array}{l}51.4 \\
48.6 \\
\end{array}$ & $\begin{array}{l}24 \\
11 \\
\end{array}$ & $\begin{array}{l}68.6 \\
31.4 \\
\end{array}$ & $\begin{array}{l}78 \\
62\end{array}$ & $\begin{array}{l}55.7 \\
44.3\end{array}$ \\
\hline Mean \pm SD & \multicolumn{2}{|c|}{$36.29 \pm 6.07$} & \multicolumn{2}{|c|}{$33.85 \pm 6.07$} & \multicolumn{2}{|c|}{$35.68 \pm 6.14$} \\
\hline $\begin{array}{ll}\text { Years of Experience } \\
\text { - } & 1-5 \\
\text { - } & 6-10 \\
\text { - } & >10\end{array}$ & $\begin{array}{c}5 \\
27 \\
73\end{array}$ & $\begin{array}{c}4.8 \\
25.7 \\
69.5\end{array}$ & $\begin{array}{c}5 \\
12 \\
18\end{array}$ & $\begin{array}{l}14.3 \\
34.3 \\
51.4\end{array}$ & $\begin{array}{l}10 \\
39 \\
91\end{array}$ & $\begin{array}{c}7.1 \\
27.9 \\
65.0\end{array}$ \\
\hline Mean \pm SD & \multicolumn{2}{|c|}{$14.28 \pm 6.11$} & \multicolumn{2}{|c|}{$11.71 \pm 6.02$} & \multicolumn{2}{|c|}{$13.64 \pm 6.17$} \\
\hline
\end{tabular}

Table (2): Agreement of the studied head nurses regarding working environment $(n=140)$

\begin{tabular}{|c|c|c|c|c|c|c|c|c|c|}
\hline \multirow{2}{*}{$\begin{array}{l}\text { Working environment } \\
\text { dimensions }\end{array}$} & \multirow{2}{*}{$\begin{array}{c}\text { MMUH } \\
(\mathbf{1 0 5}) \\
\text { EGH (35) }\end{array}$} & \multicolumn{2}{|c|}{ Disagree } & \multicolumn{2}{|c|}{ Uncertain } & \multicolumn{2}{|c|}{ Agree } & \multirow{2}{*}{$\chi^{2}$} & \multirow[t]{2}{*}{$\mathbf{P}$} \\
\hline & & $\mathbf{N}$ & $\%$ & $\mathbf{N}$ & $\%$ & $\mathbf{N}$ & $\%$ & & \\
\hline \multirow{2}{*}{ A. Facilities } & MMUH & 40 & 38.1 & 27 & 25.7 & 38 & 36.2 & \multirow[t]{2}{*}{12.01} & \multirow[t]{2}{*}{0.52} \\
\hline & EGH & 10 & 28.6 & 11 & 31.4 & 14 & 40 & & \\
\hline \multirow{2}{*}{ B. Management support } & MMUH & 11 & 10.5 & 32 & 30.5 & 62 & 59 & \multirow{2}{*}{11.94} & \multirow{2}{*}{0.45} \\
\hline & EGH & 7 & 20 & 12 & 34.3 & 16 & 45.7 & & \\
\hline \multirow{2}{*}{ C. Teamwork } & MMUH & 14 & 13.4 & 28 & 26.6 & 63 & 60 & \multirow{2}{*}{16.14} & \multirow{2}{*}{0.30} \\
\hline & EGH & 5 & 14.3 & 8 & 22.9 & 22 & 62.8 & & \\
\hline \multirow{2}{*}{ D. Safety and security } & MMUH & 16 & 15.2 & 38 & 36.2 & 51 & 48.5 & \multirow{2}{*}{15.55} & \multirow{2}{*}{0.34} \\
\hline & EGH & 7 & 20 & 11 & 31.4 & 17 & 48.6 & & \\
\hline \multirow{2}{*}{ E. Work stressors } & MMUH & 12 & 11.5 & 31 & 29.5 & 62 & 59.0 & \multirow{2}{*}{27.95} & \multirow{2}{*}{0.06} \\
\hline & EGH & 7 & 20 & 10 & 28.6 & 18 & 51.4 & & \\
\hline \multirow{2}{*}{$\begin{array}{l}\text { F. Recognition and } \\
\text { appreciation }\end{array}$} & MMUH & 12 & 11.4 & 33 & 31.4 & 60 & 57.0 & \multirow{2}{*}{19.66} & \multirow{2}{*}{0.23} \\
\hline & EGH & 8 & 22.9 & 11 & 31.4 & 16 & 45.7 & & \\
\hline \multirow{2}{*}{$\begin{array}{l}\text { Total work } \\
\text { environment }\end{array}$} & MMUH & 18 & 17.2 & 31 & 29.5 & 56 & 53.3 & \multirow{2}{*}{58.68} & \multirow{2}{*}{0.30} \\
\hline & EGH & 8 & 22.8 & 10 & 28.6 & 17 & 48.5 & & \\
\hline
\end{tabular}

MMUH: Main Mansoura University Hospital

$* p<0.05, * * p<0.01$

EGH: Elmahala General Hospital 
Table (3): Agreement of the studied head nurses regarding citizenship behavior $(n=140)$

\begin{tabular}{|c|c|c|c|c|c|c|c|c|c|}
\hline \multirow{2}{*}{$\begin{array}{l}\text { Citizenship behavior } \\
\text { dimensions }\end{array}$} & \multirow{2}{*}{$\begin{array}{c}\text { MMUH } \\
(105)\end{array}$} & \multicolumn{2}{|c|}{ Disagree } & \multicolumn{2}{|c|}{ Uncertain } & \multicolumn{2}{|c|}{ Agree } & \multirow{2}{*}{$\chi^{2}$} & \multirow{2}{*}{$\mathbf{P}$} \\
\hline & & $\mathbf{N}$ & $\%$ & $\mathbf{N}$ & $\%$ & $\mathbf{N}$ & $\%$ & & \\
\hline \multirow{2}{*}{ A. Training and development } & MMUH & 15 & 14.3 & 40 & 38.1 & 50 & 47.6 & \multirow{2}{*}{19.16} & \multirow{2}{*}{$\mathbf{0 . 0 3 *}$} \\
\hline & EGH & 5 & 14.3 & 12 & 34.3 & 18 & 51.4 & & \\
\hline \multirow{2}{*}{ B. Work life policies } & MMUH & 17 & 16.2 & 45 & 42.9 & 43 & 40.9 & \multirow[b]{2}{*}{21.91} & \multirow[b]{2}{*}{$0.005 * *$} \\
\hline & EGH & 5 & 14.3 & 12 & 34.3 & 18 & 51.4 & & \\
\hline \multirow{2}{*}{ C. Empowerment practices } & MMUH & 13 & 12.4 & 46 & 43.8 & 46 & 43.8 & \multirow{2}{*}{32.00} & \multirow{2}{*}{$0.001 * *$} \\
\hline & & 9 & 25.7 & 11 & 31.4 & 15 & 42.9 & & \\
\hline \multirow{2}{*}{ D. Organizational commitment } & MMUH & 17 & 16.2 & 41 & 39.0 & 47 & 44.8 & \multirow{2}{*}{12.80} & \multirow{2}{*}{0.46} \\
\hline & EGH & 7 & 20.0 & 11 & 31.4 & 17 & 48.6 & & \\
\hline \multirow{2}{*}{$\begin{array}{l}\text { E. Interpersonal } \\
\text { behavior }\end{array}$} & MMUH & 14 & 13.3 & 41 & 39.0 & 50 & 47.7 & \multirow[b]{2}{*}{8.20} & \multirow[b]{2}{*}{0.87} \\
\hline & EGH & 5 & 14.3 & 13 & 37.1 & 17 & 48.6 & & \\
\hline \multirow{2}{*}{ Total citizenship behavior } & MMUH & 15 & 14.3 & 43 & 40.9 & 47 & 44.8 & \multirow{2}{*}{64.28} & \multirow{2}{*}{$\mathbf{0 . 0 3 *}$} \\
\hline & EGH & 6 & 17.1 & 12 & 34.3 & 17 & 48.6 & & \\
\hline
\end{tabular}

MMUH: Main Mansoura University Hospital EGH: Elmahala General Hospital

$* p<0.05, * * p<0.01$

Table (4): Agreement of the studied head nurses regarding managerial innovation $(n=140)$.

\begin{tabular}{|c|c|c|c|c|c|c|c|c|c|}
\hline \multirow[b]{2}{*}{ Items } & \multirow{2}{*}{$\begin{array}{l}\text { MMU } \\
\text { H (105) } \\
\text { EGH } \\
(\mathbf{3 5})\end{array}$} & \multicolumn{2}{|c|}{ Disagree } & \multicolumn{2}{|c|}{ Uncertain } & \multicolumn{2}{|c|}{ Agree } & \multirow[b]{2}{*}{$\chi^{2}$} & \multirow[b]{2}{*}{$\mathbf{P}$} \\
\hline & & $\mathbf{N}$ & $\%$ & $\mathbf{N}$ & $\%$ & $\mathbf{N}$ & $\%$ & & \\
\hline \multirow{2}{*}{$\begin{array}{l}\text { 1. I always look for new ways to } \\
\text { manage my team }\end{array}$} & MMUH & 15 & 14.3 & 32 & 30.5 & 58 & 55.2 & \multirow{2}{*}{12.71} & \multirow{2}{*}{$0.01 * *$} \\
\hline & EGH & 6 & 17.2 & 6 & 17.1 & 23 & 65.7 & & \\
\hline \multirow{2}{*}{$\begin{array}{l}\text { 2. I do not manage in a } \\
\text { conventional way }\end{array}$} & MMUH & 19 & 18.1 & 27 & 25.7 & 59 & 56.2 & \multirow{2}{*}{1.99} & \multirow{2}{*}{0.74} \\
\hline & EGH & 4 & 11.4 & 9 & 25.7 & 22 & 62.9 & & \\
\hline $\begin{array}{l}\text { 3. New ideas and ways are always } \\
\text { good and are welcomed. }\end{array}$ & MMUH & 14 & 13.4 & 20 & $\frac{19.0}{25.7}$ & 71 & 67.6 & 15.34 & $0.01 * *$ \\
\hline \multirow{2}{*}{$\begin{array}{l}\text { 4. Managing innovatively creates } \\
\text { long lasting advantages for the } \\
\text { organization }\end{array}$} & MMUH & 10 & 9.5 & 21 & 20.0 & 74 & 70.5 & \multirow{2}{*}{11.46} & \multirow{2}{*}{ 0.02* } \\
\hline & EGH & 10 & 28.6 & 9 & 25.7 & 16 & 45.7 & & \\
\hline \multirow{2}{*}{$\begin{array}{l}\text { 5. When I manage my team } \\
\text { innovatively I skip the pitfalls of } \\
\text { conventional management }\end{array}$} & MMUH & 18 & 17.2 & 26 & 24.8 & 61 & 58.1 & \multirow[b]{2}{*}{6.67} & \multirow[t]{2}{*}{0.15} \\
\hline & EGH & 8 & 22.9 & 8 & 22.9 & 19 & 54.3 & & \\
\hline \multirow{2}{*}{$\begin{array}{l}\text { 6. Innovation is based on a novel } \\
\text { principle that challenges } \\
\text { management's orthodoxy }\end{array}$} & MMUH & 15 & 14.3 & 33 & 31.4 & 57 & 54.2 & \multirow{2}{*}{5.33} & \multirow{2}{*}{0.25} \\
\hline & EGH & 1 & 20 & 15 & 42.7 & 13 & 37.3 & & \\
\hline $\begin{array}{l}\text { 7. An innovative manager develops } \\
\text { skills and talents of employees }\end{array}$ & MMUH & 8 & 7.6 & 25 & 23.8 & 72 & $\begin{array}{l}68.6 \\
57.1\end{array}$ & 5.39 & 0.24 \\
\hline \multirow{2}{*}{$\begin{array}{l}\text { 8. Managing innovatively can } \\
\text { influence ethical aspects of } \\
\text { management }\end{array}$} & $\frac{\text { EGH }}{\text { MMUH }}$ & $\frac{5}{13}$ & $\begin{array}{l}14.3 \\
12.4\end{array}$ & $\frac{10}{30}$ & $\frac{28.6}{28.6}$ & $\frac{20}{62}$ & $\begin{array}{l}57.1 \\
59.1\end{array}$ & \multirow[b]{2}{*}{4.37} & \multirow[t]{2}{*}{0.35} \\
\hline & EGH & 8 & 22.9 & 7 & 20.0 & 20 & 57.1 & & \\
\hline Total & $\begin{array}{l}\text { MMUH } \\
\text { FGH }\end{array}$ & $\frac{14}{8}$ & $\begin{array}{l}13.3 \\
228\end{array}$ & $\frac{27}{8}$ & $\frac{25.7}{229}$ & $\begin{array}{l}64 \\
19\end{array}$ & $\begin{array}{l}61.0 \\
543\end{array}$ & 28.01 & 0.13 \\
\hline
\end{tabular}

MMUH: Main Mansoura University Hospital

$* p<0.05, * * p<0.01$

Table (5): Levels of working environment, citizenship behavior and managerial innovation among the studied head nurses.

\begin{tabular}{|c|c|c|c|c|c|c|c|c|c|}
\hline \multirow{2}{*}{\multicolumn{2}{|c|}{ Variables }} & \multicolumn{2}{|c|}{$\underset{(<50 \%)}{\text { Low }}$} & \multicolumn{2}{|c|}{$\begin{array}{c}\text { Moderate } \\
(\mathbf{5 0 \%}-\mathbf{7 5 \%})\end{array}$} & \multicolumn{2}{|c|}{$\begin{array}{c}\text { High } \\
(>75 \%)\end{array}$} & \multirow[t]{2}{*}{$\chi^{2}$} & \multirow[t]{2}{*}{ P* } \\
\hline & & $\mathbf{N}$ & $\%$ & $\mathbf{N}$ & $\%$ & $\mathbf{N}$ & $\%$ & & \\
\hline \multirow{2}{*}{ Working environment } & MMUH $(n=105)$ & 3 & 2.9 & 75 & 71.4 & 27 & 25.7 & \multirow{2}{*}{0.43} & \multirow{2}{*}{0.85} \\
\hline & EGH $(n=35)$ & 1 & 2.9 & 23 & 65.7 & 11 & 31.4 & & \\
\hline \multirow{2}{*}{ Citizenship behavior } & MMUH $(\mathrm{n}=105)$ & $\frac{2}{4}$ & 1.9 & 41 & 39.0 & 62 & 59.0 & \multirow{2}{*}{6.32} & \multirow{2}{*}{$0.04 *$} \\
\hline & EGH $(n=35)$ & 0 & 0.0 & 22 & 62.9 & 13 & 37.1 & & \\
\hline \multirow{2}{*}{ Managerial innovation } & MMUH $(\mathrm{n}=105)$ & 1 & 1.0 & 61 & 58.1 & 43 & 41.0 & \multirow{2}{*}{4.89} & \multirow{2}{*}{0.06} \\
\hline & $\mathrm{EGH}(\mathrm{n}=35)$ & 2 & 5.7 & 24 & 68.6 & 9 & 25.7 & & \\
\hline
\end{tabular}

MMUH: Main Mansoura University Hospital

EGH: Elmahala General Hospital 


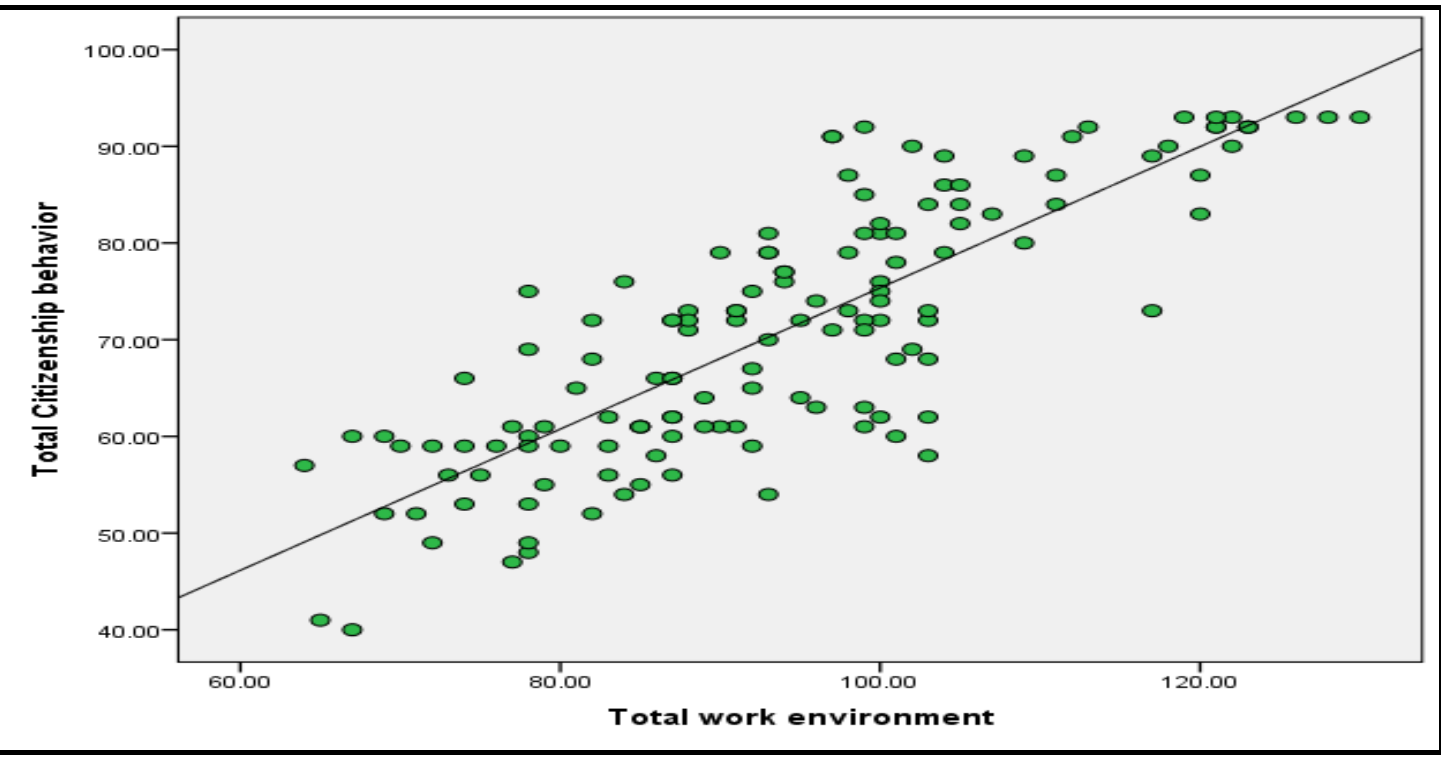

Figure (1): Relationship between total working environment and total citizenship behavior as perceived by the studied head nurses $(n=140)$

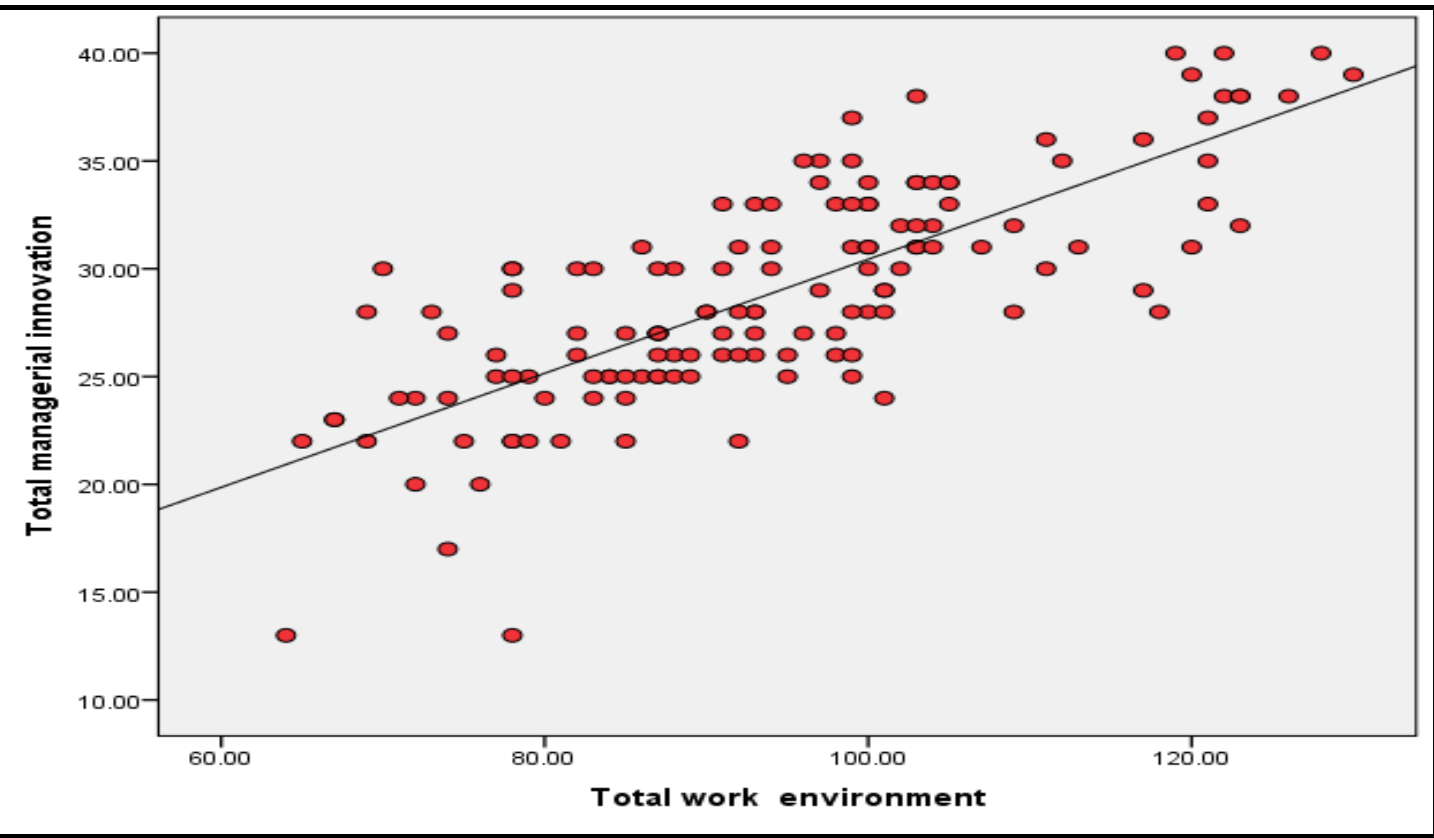

Figure (2): Relationship between total working environment and total managerial innovation as perceived by the studied head nurses $(n=140)$

Table (6): Correlation between total working environment, citizenship behavior and managerial innovation as perceived by the studied head nurses $(n=140)$

\begin{tabular}{|l|c|c|c|c|c|c|}
\hline \multirow{3}{*}{ Variables } & \multicolumn{6}{|c|}{ Total working environment score } \\
\cline { 2 - 7 } & \multicolumn{2}{|c|}{ MMUH (n= 105) } & \multicolumn{2}{c|}{ EGH $(\mathbf{n}=\mathbf{3 5})$} & \multicolumn{2}{c|}{ Total $(\mathbf{n = 1 4 0})$} \\
\cline { 2 - 7 } & $\mathbf{R}$ & $\mathbf{p}$ & $\mathbf{r}$ & $\mathbf{p}$ & $\mathbf{r}$ & $\mathbf{p}$ \\
\hline Total managerial innovation & 0.80 & $0.000^{* *}$ & 0.70 & $0.000^{* *}$ & 0.77 & $0.000^{* *}$ \\
\hline Total citizenship behavior & 0.80 & $0.000^{* *}$ & 0.87 & $0.000^{* *}$ & 0.82 & $0.000^{* *}$ \\
\hline
\end{tabular}

MMUH: Main Mansoura University Hospital

$* p<0.05 / * * p<0.01$ 
Table (1): Showed personal characteristics of the studied head nurses. According to the table mean age at Mansoura University Hospital was higher than that of Elmahala General Hospital (36.29 4.07 , $33.85 \pm 6.07$ ) respectively. Regarding years of experience, mean years of experience at Main University Hospital was higher than that of Elmahala General Hospital (14.28 $\pm 6.11, \quad 11.71 \pm 6.02)$ respectively.

Table (2): Represents agreement of the studied head nurses regarding working environment. According to this table, agreement to total working environment at Main Mansoura University Hospital was higher $(53.3 \%)$ than Elmahala General Hospital (48.5\%). In relation to working environment dimensions, the highest percentage was $(62.8 \%)$ related to team work at Elmahala General Hospital, and the lowest was facilities at two hospitals. There is no significance differences between total working environment and its dimensions.

Table (3): Represents agreement of the studied head nurses regarding citizenship behavior. According to the table, The total highest of citizenship behavior agreement was at Elmahala General Hospital (48.6\%) rather than Main Mansoura University Hospital $(44.8 \%)$. As regard to dimensions of citizenship behavior, the highest agreement related to training and development at Elmahala General Hospital $(51.4 \%)$, while the lowest was related to work life policies $(40.9 \%)$ at Main Mansoura University Hospital. There are significance differences between total and dimensions of citizenship behavior except in organizational commitment and interpersonal harmony behavior $(* \mathrm{p}<0.05)$.

Table (4): Showed agreement of the studied head nurses regarding managerial innovation. According to the table, Agreement of managerial innovation was higher at Main university hospital than at Elmahala General Hospital $(61.0 \%, 54.3 \%)$ respectively. There was highly statistically significant difference related to item of I always look for new ways to manage my team at Elmhala General Hospital than at Main University Hospital (** $\mathrm{p} \leq 0.01)$. Also related to item of new ideas and ways are always good and are welcomed and managing innovatively creates long lasting advantages for the organization at Main University Hospital than at Elmahla General Hospital (** $\mathrm{p} \leq 0.01)$. Also, there is a significance difference to managing innovatively creates long lasting advantages for the organization at Main University Hospital than at Elmahla General Hospital (*p< 0.05)

Table (5): Represents levels of working environment, citizenship behavior and managerial innovation among the studied head nurses. Regarding level of working environment, nearly more than two thirds of head nurses perceived moderate level of working environment at Main Mansoura University and \& Elmahala General Hospital (71.4\%, 65.7\%) respectively. Regarding level of citizenship behavior, more than two thirds of head nurses $(59.0 \%)$ showed high level at Main Mansoura University and moderate level at Elmahala General Hospital (62.9\%). Finally, regarding level of managerial innovation more than half of head nurses $(58.1 \%)$ perceived moderate level at Main Mansoura University and more than two thirds of them ( $68.6 \%$ ) perceived moderate level at Elmahala General Hospital. There is significance difference related to level of citizenship behavior at main university hospital higher than at Emahala General Hospital (*p<0.05).

Figure (1): Illustrated relationship between total working environment and total citizenship behavior as perceived by studied head nurses, there is a significance relation between total working environment and total citizenship behavior $(* * \mathrm{p}$ $<0.01$ )

Figure (2): Illustrated relationship between total working environment and total managerial innovation as perceived by studied head nurses, there is a significance relation between total working environment and total managerial innovation $(* * \mathrm{p}$ $<0.01)$

Table (6): represents correlation between total working environment and both total of citizenship behavior and managerial innovation as perceived by studied head nurses in both setting. There is a strong statistically significant positive correlation between total working environment and both total of citizenship behavior and managerial innovation in both setting $(* * \mathrm{p}<0.01)$

\section{Discussion}

Working environment consists of an important factors that affects all head nurses performance. Attractive and supportive working environment is essential to improve managerial innovation and organizational citizenship behavior, especially during this time of continuous alteration and challenge (Wuisan, et al., 2020).

The finding of the present study showed that agreement to total working environment at Main university hospital was higher than Elmahala General Hospital. This may due to that agreement of participants to management support, recognition and appreciation at Main Mansoura University Hospital was higher than Elmahala General Hospital. Head nurses at Main Mansoura University Hospital continuously find what they want in the department, and the department is well prepared, the organization enjoys a good level of infrastructure, and advanced management recognizes their efforts. 
The result of the current study showed that more than two thirds of head nurses showed highly moderate level of working environment. This may due to that working as a team, accessibility of management support that offers guidance and help when wanted and appreciation for head nurses. In agreement of the current study, Sinnappan (2017) specified that the majority of the respondents stated that their working environment was good, and they were pleased with the general environment of their working area. This was confirmed by Al-Omari \& Okasheh (2017) who specified that nurses are sense positive about their working environment and a lot of them were at ease with their working environment, mostly because of the individuals that they work with them and support that they getting made them feel good being at work and sensed optimistic with their working environment.

Aditionally, Massoudi \& Hamdi, (2017) said that most of the study sample were pleased with the overall working environment, and are happy to be a part of the association. This was in the same line with Sutanto, et al., (2018) who mentioned that workers sense that the working environment is relaxed and added that a relaxed working environment will make employees to feel at home in their work place, and help persons be more stressed on their job. On the contrast, Sinnappan, (2017) found that nurses evaluated their working environment as bad.

Regarding working environment dimensions, the result of the existing study showed that teamwork was the highest dimension of working environment at Elmahala General Hospital. This may be due to that head nurses manage and lead as one family in the department, working such as a team provides them with the space to be innovative and they have the essential level of understanding with their team. This was consistent with Ramadan, (2018) who stated that nursing staff assessed the teamwork as the highest component and mentioned that a supportive working environment would have a work team that supports its groups in their efforts to equilibrium work and family, adding that teamwork really plays an enormous role in cultivating working environment. This also was supported by Agbozo, et al., (2017) who establish that nurses stated team work as the highest domain and said that working environment is related to teamwork as they must to work along with their colleagues or rely on them to accomplish their everyday activities.

Conversely, the recent study revealed that facilities was the lowest dimension of working environment at two hospitals. This may because that head nurses continuously not find what they want in the unit and the unit that they manage is not well equipped. This was in congruent with Alabduljader, (2019) who revealed that supervisors scored facilities in bad level confirming that it plays very significant role in their working environment and assist them to finish duties within the timeline. This was in the same line with Ramos, et al., (2018) who discovered that nurses gave facilities the lowest score, and stated that having adequate facilities assist healthcare staffs to perform their roles competently and successfully, and has an essential effect on their capability to provide high quality care.

The result of the existing study showed that agreement to total organizational citizenship behaviors at Elmahala general hospital was higher than at Main Mansoura university hospital. This may because that agreement of participants to work life policies, training and development and organizational commitment at Elmahala general hospital was higher than at Main Mansoura university hospital.

The finding of the present study revealed that approximately two thirds of head nurses displayed high level of organizational citizenship behaviors at Main Mansoura University Hospital and more than two thirds of them displayed moderate level of citizenship behaviors at Elmahala General Hospital. This was supported by Hossein \& Somayeh, (2018) who concluded that the level of OCB among the staff was at a higher-than-average rate. This also in the same line with, Andrade, et al., (2016) who stated that OCB and its dimensions were at a preferred level among the studied staff. Additionally, Ngugi, (2017) found that OCB was above the satisfactory level, adding that nurses showed good level of OCB and its dimensions. On the contrast, Abed \& Elewa (2016) indicated that the rate of OCB was lesser than average amongst the staff of teaching hospitals at Singapore. Concerning organizational citizenship behaviors dimensions, The finding of the present study presented that the highest agreement related to training and development at Elmahala General Hospital. This may due to that hospital is offering job specific training for head nurses, allocating enough time for training, giving them a chance to be involved in actions that enhance their professional growth and they can apply training in their hospital. This was in the same line with Adnans, et al., (2020) who identified that more than two-thirds of head nurses agree that they obtain training regarding their work. Declaring that greatest hospitals follows the programs of quality and training and development is one of quality programs phases for developing health services.

Also, Erdirencelebi \& Akcan, (2016) revealed that training and development advance nurse's capabilities as well as improve the potential competence of all contributors of the work group to accomplish well. The greatest excellent settings to work are settings 
where nurses are provided with education and chances to develop. Enhancing professional practice and raising nurses' clinical skills through ongoing training maintaining them up-to-date and elevate their pleasure with their working environment.

On the other hand, the present study displayed that the lowest agreement of organizational citizenship behaviors dimensions was related to work life policies at Main Mansoura university hospital. This may due to that head nurses' work schedule is repeatedly in conflict with their personal life, they frequently feel that there is too much work to do and their job affects negatively on their personal life and their role as a spouse /or apparent. This was supported by Abd- Elmohsen, (2017) who specified that work life policies was the lowest and last domain, completed that inflexible work schedule and high work load and stressors are basic sources for conflict between personal life and work. In the same line, Hermawan, et al., (2020) clarified that work life policies is one of the highest employee' concerns and organizations and employees are becoming increasingly attentive to the potential advantages of work-life balance and related work-life balance policies.

The result of the current study exposed that managerial innovation was higher at Main Mansoura University Hospital than at Elmahala General Hospital. This may because of agreement of head nurses to managing innovatively creates permanent benefits for the organization, novel ideas and methods are constantly good and are welcomed, as well as an innovative manager enhances skills and talents of staffs at Main Mansoura University Hospital was higher than Elmahala General Hospital.

The result of the existent study showed that nearly two thirds of head nurses at Main Mansoura university hospital and more than two thirds of them at Elmahala General Hospital displayed moderate level of managerial innovation. This result congruent with Lin, et al., (2020) who found (exposed) that managerial innovation was good and supervisors in places of power, with robust professional networks, and with arrival to organizational resources are more energetic innovators. Additionally, Drosos, et al., (2021) said that innovative ideas and services implemented by nurses is becoming increasingly common today, confirming that managers who share novel thoughts with similar-minded colleagues may be able to create novel knowledge, organize activities, and ultimately be more likely to implement innovative performs within and across organizations. On the contrast, Kaya, et al., (2015) stated that managerial innovation is somewhat poor and managers want to endure in mind the importance and necessity of innovation.
Regarding managerial innovation dimensions, the result of the current study specified that managing innovatively generates permanent benefits for the association which was the highest mean of innovation dimension at Main Mansoura University Hospital. This was supported by Asurakkody \& Shin., (2018) who identified that innovative manager simplifying novel thinking, novel thoughts, and novel method of working among the staffs which support their knowledge and practice to enhance their performance. This also in the same line with Alabduljader, (2019) who stated that managers have a positive attitudes toward this statement and ranked it as the highest and good. Furthermore, Merih, (2021) declared that managerial innovation is a significant issue and critical manner for organizational effectiveness as well as competitiveness, it provides them with positive feeling and motivating them to do their bests and exceed their basic job needs.

On the other hand, the present study showing that innovation is established on a new principle that challenges management's orthodoxy had the lowest innovation dimension at Elmahala general hospital. In agreement of the present study, Khan, et al., (2018) indicated that above half of supervisors strongly agreed that they repeatedly search for novel thoughts to use in their work, and make use of these novel ideas. Over a third of them informed that they take an innovative method to their work. On the contrast, Brysiewicz, et al., (2015) found that most managers utilizing traditional ways in their management and reject the change in their practice and avoid the novel thoughts and ways.

Concerning relationship between working environment and citizenship behavior among head nurses, the findings of the existing study showed that there was a statistically significant positive relationship between working environment and citizenship behavior. This may due to that good working environment inspire head nurses to do their best as well as encourage them to behave like citizens. This was in congruent with Mahmoud \& Abd El Azim, (2016) who identified that the perceived working environment is closely linked with OCB.

This also was in the same line with Rachman, (2019) who told that sufficient facilities and management support play a significant role to staffs, offer them with persistent reassurance, guidance and right information that rise worker's self-confidence as well as stimulate them to behave like citizenships. Moreover, Akinwale \& George, (2020) declared that healthy working environment provides a satisfactory environment for work, copes with stress, eases workers relations and work life balance creating staffs 
pleasure as well as convincing them to behave like citizens.

As regard to relationship between working environment and managerial innovation among head nurses, the findings of the existent study discovered that there was a statistically significant positive relationship between working environment and managerial innovation. This may because that good working environment improve thinking and nurture new ideas and practice while bad working environment hinder them. This finding was in the same line with Khan, et al., (2018) who specified that working environment was the chief and real driver of managerial innovation. This also was supported by Ramadan, (2018) who showing that innovation must be go with a healthy working environment that assist managers to think, generate in addition to innovate.

Additionally, Beardsmore \& McSherry, (2017) declared that the highest obstacles for innovation was the working environment approving that positive working environment stimulate the staffs to innovate. Also, Velickovska, (2017) told that healthy working environment has the ability to inspire innovation as well as creativeness amongst workers in the association.

\section{Conclusion}

More than two thirds of head nurses presented highly moderate level of working environment at two hospitals. Nearly two thirds of head nurses revealed high level of organizational citizenship behaviors at Main Mansoura University Hospital and more than two thirds of them displayed moderate level of organizational citizenship behaviors at Elmahala General Hospital. Nearly two thirds of them at Main Mansoura university hospital and more than two thirds of them at Elmahala General Hospital displayed moderate level of managerial innovation .There were statistically significant positive relationships between working environment and both organizational citizenship behaviors and managerial innovation. Therefore, from the above we can decided that there is a probability of enhancing organizational citizenship behaviors and managerial innovation throughout enhancing their working environment.

\section{Recommendations}

- Healthcare administrators must focus and strive to improve healthcare working environment that nurtures organizational citizenship behavior and innovation, detecting that they require positive working environment.

- Authorities want to buying and providing recent and novel equipment, quickly maintenance and repairs of broken and old equipment and trying to provide needed facilities as possible.

- Administrators should offer elasticity of scheduling and equilibrium among nurses' family life and the needs of their work.

- Implement innovative strategies to support the development of professional knowledge, talents and capabilities of head nurse.

- Hospital administrators holding meetings with the head nurses to explain the constructive and predictable outcomes associated with managerial innovation and confirming that it has been routinized into the everyday organizational acts.

- Including head nurses in establishing goals and decisions of organizations to improve the organizational citizenship behavior.

- Design a new appraisal method consist of assessing for extra-role behaviors.

- Further research must be conducted about managerial innovation and its effect on organizations.

\section{References}

- Abd- Elmohsen, A., (2017): Internal Marketing and Organizational Citizenship Behavior: A comparative Study in Mansoura. Published Master Thesis. Mansoura University. Faculty of Nursing. 35-38.

- Abed, F., \& Elewa, H., (2016): The Relationship between Organizational Support, Work Engagement and Organizational Citizenship Behavior as Perceived by Staff Nurses at Different Hospitals. Journal of Nursing and Health Science. 5 (4), 113-123.

- Adnans, A., Ginting, E., Silvana, \& Rizal, A., (2020): Organizational Citizenship Behavior on Nurses: The Role of Organizational Commitment and Job Satisfaction. International Journal of Advanced Science and Technology. 29 (7), 43154321.

- Agbozo, K., Owusu, S, Mabel A. Hoedoafia1, A, \& Atakorah, B, (2017): The Effect of Work Environment on Job Satisfaction: Evidence from the Banking Sector in Ghana. Journal of Human Resource Management. 5(1): 12-18.

- Akbari, M., Bagheri, A., Imani, S., \& Asadnezhad, M., (2021): Does entrepreneurial leadership encourage innovation work behavior? The mediating role of creative self-efficacy and support for innovation. European Journal of Innovation Management. 24 (1), 1-22. DOI 10.1108/EJIM-10-2019-0283.

- Akinwale, O., \& George, O., (2020): Work environment and job satisfaction among nurses in government tertiary hospitals in Nigeria. Rajagiri 
Management

Journal

14 (1), 71-92

- Alabduljader, A, (2019): The effective role of work environment and its influence on managerial innovation. Management Science Letters 9. 91104.

- Al-Omari, K., \& Okasheh, H. (2017): The Influence of Work Environment on Job Performance: A Case Study of Engineering Company in Jordan. International Journal of Applied Engineering Research, 12(24), 1554415550 .

- Andrade, T., Estivalete, V., Costa, F., \& Avila, G., (2016): Organizational Citizenship Behaviors, Trust and Organizational Support: Framework Analysis Proposition. Revista Espacios. 38 (4).

- Asurakkody, T., \& Shin, Y., (2018): Innovative Behavior in Nursing Context: A Concept Analysis. Asian Nursing Research. 12, 237-244.

- Asurakkody, T., \& Kim, S., (2020): Effects of knowledge sharing behavior on innovative work behavior amongnursing Students: Mediating role of Self- leadership. International Journal of Africa Nursing Sciences. 12 (1), 1-6.

- Awang, A., Sapie, N., Hussain, M., Ishak, S., \& Yusof, R., (2019): Nurturing innovative employees: effects of organizational learning and work environment. Economic ResearchEkonomska Istrazivanja. 32 (1), 1152-1168.

- Beardsmore, E., \& McSherry, R., (2017): Healthcare workers' perceptions of organizational culture and the impact on the delivery of compassionate quality care. Journal of Research in Nursing. 22(1-2) 42-56.

- Bellini, D., Ramaci, T., Bonaiuto, M., Cubico, S., Favretto, G., \& Johnsen, S., (2019): Exploring the influence of working environments' restorative quality on organizational citizenship behaviors. International Journal of Environment, Workplace and Employment. 5 (1), 33-50.

- Brysiewicz, P, Hughes, L, \& McCreary, L, (2015): Promoting Innovation in Global Nursing Practice. Rwanda Journal Series F: Medicine and Health Sciences. 2 (2): 41-45.

- Drosos, D., Kyriakopoulos, G., Gkika, E., Komisopoulos, F., Skordoulis, M., \& Ntanos, S., (2021): Managing Change and Managerial Innovation towards Employees Satisfaction at Workplace. TEM Journal. 10 (2), 597-606.

- Erdirencelebi, M., \& Akcan, T, (2016): Effects of Ethical Climate on the Organizational Citizenship Perceptions and Performance of Employees. International Journal of Recent Advances in Organizational Behaviour and Decision Sciences. 2 (3), 793-808.
- Fox, S., \& Paul, E., (2011): Job satisfaction and organizational citizenship behavior: An empirical study of higher learning institutions. Asian Academy of Management Journal, 16 (2), 149165.

- Hermawan, H., Thamrin, H., \& Susilo, P., (2020): Organizational Citizenship Behavior and Performance: The Role of Employee Engagement. Journal of Asian Finance, Economics and Business. 7 (12), 1089-1097.

- Hossain, M., (2020): Organizational Citizenship Behavior and Organizational Commitment among Clinical Nurses in Bangladesh. Open Journal of Nursing. 10 (7), 693-704. doi: 10.4236/ojn.2020.107049.

- Hossein, D., \& Somayeh, K., (2018): Organizational Citizenship Behaviors and Counterproductive Work Behaviors: A Study of Tehran University of Medical Sciences Staff. Review of Public Administration and Management. 6 (2). 215-224.

- Kaya, N, Turan, N, \& Aydin, O, (2015): A Concept Analysis of Innovation in Nursing. World Conference on Technology, Innovation and Entrepreneurship. Social and Behavioral Sciences. Available online at www.sciencedirect.com 195, 1674 - 1678.

- Khan, K, Memon, A, \& Ramayah, T (2018): Leadership and Innovative Culture Influence on Organizational Citizenship Behavior and Effective Commitment: The Mediating Role of Interactional Justice. International Journal of Business and Society. 19 (3). 725-747.

- Lin, W., Zhong, W., Su, C., \& Chen, P., (2020): Are Pressuring Employees to Improve Organizational Innovation Still Working? An Empirical Analysis of Manufacturing Companies in China. SAGE Open. 1-13. DOI: $10.1177 / 2158244020963065$.

journals.sagepub.com/home/sgo.

- Mahmoud, S., \& Abd El Azim, I., (2016): Factors in Nurses' Organizational Citizenship Behavior. Journal of Nursing and Health Science. www.iosrjournals.org 5 (2) : 22-28.

- Massoudi, H, A., \& Hamdi, A, S., (2017): The Consequence of work environment on Employees Productivity. Journal of Business and Management. 19 (1). 35-42.

- Merih, Y., (2021): The Roles of Innovative Nurses in the COVID-19 during the Pandemic and Difficulties They Experience. Journal of Education and Research in Nursing. 18 (1): 69-75.

- Najm, N., \& Alhmeidiyeen, M., (2019): Managerial Innovation: An Attempt to Interpretation and Evaluation. Review of Applied 
Socio- Economic Research 17 (1), 53-68.

- Ngugi, J., (2017): Role of Working Conditions on Organization Citizenship Behaviour in the Banking Industry: A Survey of Barclays Bank in North Rift Region. Journal of Business and Management. 19 (6). 32-37.

- Omidi, M., Meftahi, H., \& Omidi, N., (2018): The Relationship between Organizational Citizen Behavior and Nursing Achievement Motivation. Journal of Health Management and Informatics. 5 (3), 111-117.

- Pranitasari, D., (2019): The Effect of Managerial Effectiveness, Work Environment, and Team Work on Lecturer's Work Engagement. International Journal of Innovative Technology and Exploring Engineering. 8 (12), 2536 - 2542.

- Rachman, M., (2019): The Influence of the Work Environment, Organizational Commitment and Organizational Citizenship Behavior on Employee Performance and Motivation as Intervening. European Journal of Business and Management. 11 (35), Available at SSRN: https://ssrn.com/abstract=3693906.

- Ramadan, E., (2018): Impact of Work Environment on achieving managerial innovation. Middle East Journal for Scientific Publishing. 1 (3), 22-31.

- Ramos, M., Figueiredo, P., \& Guizzo, C., (2018): Antecedents of innovation in industry. Innovation \& Management Review. 15 (3), 269-285.DOI 10.1108/INMR-05-20180032.

- Sinnappan, T., (2017): Working Environment and its Influence on Employees' Performance: A Case Study of an Oil and Gas Vender Company in Malaysia. Published Master Thesis. Faculty of Accountancy and Management. University Tunku Abdul Rahman.25-29.

- Sutanto, M., Sampson, S., \& Mulyono, F., (2018): Organizational Justice, Work Environment and Motivation. International Journal of Business and Society, 19 (2), 313-322.

- Utami, S., Sanusi, A., \& Respati, H., (2020): The Effect of Organizational Citizenship Behaviors on Nurses Performance through Nurse's Work Satisfaction in Hospital in Kediri, East Java, Indonesia. International Journal of Advances in Scientific Research and Engineering. 6 (11), 6574.

- Velickovska, I., (2017): Organizational Citizenship Behavior: Definition, Determinants and Effects. Engineering Management Journal. 3 (1) $40-51$.

- Weintraub, P., \& McKee, M., (2019): Leadership for Innovation in Healthcare: An
Exploration. International Journal of Health Policy and Management. 8(3), 138-144.

- Wuisan, D., Meilani, Y., \& Sutawidjaya, A., (2020): The influence of organizational commitment, work satisfaction, and organizational culture to behavior organizational citizenship. International Journal of Research in Commerce and Management Studies. 2 (2). 136153.

- Zhang, Y., Khan, U., Lee, S., \& Salik, M., (2018): The Influence of Management Innovation and Technological Innovation on Organization Performance. A Mediating Role of Sustainability. Sustainability. 11(495). 